\title{
Morphological and Histological Evaluations of In Vitro Regeneration in Elliottia racemosa Leaf Explants Induced on Media with Thidiazuron
}

\author{
Seong Min Woo and Hazel Y. Wetzstein ${ }^{1}$ \\ Department of Horticulture, 1111 Miller Plant Sciences Building, University of Georgia, Athens, \\ GA 30602-7273
}

\begin{abstract}
AdDitional INDEX wORDs. histology, organogenesis, somatic embryogenesis, TDZ
Abstract. Georgia plume (Elliottia racemosa Muhlenb. ex. Elliott) is a rare deciduous shrub or small tree. It has sustained severe loss of habitat and its range is now restricted to a limited number of sites in the state of Georgia. Tissue culture protocols have been developed as a means to propagate and conserve this threatened species using leaf explants induced on medium supplemented with $10 \mu \mathrm{M}$ thidiazuron (TDZ) and $5 \mu \mathrm{M}$ indole-3-acetic acid (IAA). Budlike clusters, elongated embryo-like protrusions, and shoot-like structures were produced from the leaf explants. Morphological and histological evaluations of cultures during induction and development were conducted using light microscopy of sectioned material and scanning electron micrography. Histology of explant tissues indicates that plant regeneration of Georgia plume occurs through a shoot organogenesis pathway that involves the formation of actively dividing meristematic regions originating in subepidermal cell layers that proliferate to form protuberances on the explant surface. Numerous well-formed shoot apical meristems with leaf primordia are produced, as well as fused shoot-like structures. Elongated, embryo-like structures had various degrees of shoot apex development. Evaluations of serial sections found that they lacked a defined root apex, and that basal portions were composed of parenchymatous files of cells with a broad point of attachment to the parent tissue. The lack of bipolarity and a root pole signifies that true somatic embryogenesis does not occur.
\end{abstract}

Elliottia racemosa, commonly called Georgia plume, is a rare deciduous shrub or small tree native to the state of Georgia. In early summer, it has beautiful plume-like clusters of white flowers from which it gets its name. Attaining heights up to $10 \mathrm{~m}$ or taller, specimens often have multiple branches that form from resprouting of shoots from roots. A member of the Ericaceae, Georgia plume was first collected by William Bartram in 1773, and was not observed again until 1808 when it was collected by Stephen Elliott for whom it was named (Ewan, 1968; Patrick et al., 1995). It was thought to be extinct in the wild from 1875 until 1901 when it was rediscovered. Georgia plume is one of the rarest native large shrubs, and has a very limited range restricted to about three dozen locations in Georgia (Patrick et al., 1995).

Georgia plume has not been known or studied broadly, even though this species was introduced in 1813. However, low pollen viability, self incompatibility, a low or nonexistent seed set, and a lack of sexual recruitment are important factors threatening reproduction in this species (Godt and Hamrick, 1999). Young seedling plants have not been found in the wild (Bozeman and Roger, 1983), indicating serious consequences for the future. Georgia plume has sustained a severe loss of habitat from the loss of forests in agricultural production.

Tissue culture can be an excellent approach for propagation and conservation of threatened or endangered species (Fay, 1992). This is particularly the case when, as in Georgia plume, conventional propagation methods are ineffective or limiting. A conservation program incorporating in vitro propagation can provide a means for plant reintroduction, augmentation of

Received for publication 30 Aug. 2007. Accepted for publication 9 Jan. 2008. We thank Gwen Hirsch for her technical assistance.

${ }^{1}$ Corresponding author. E-mail: hywetz@uga.edu. existing populations, and safeguarding of germplasm. An efficient plant regeneration system was developed for the micropropagation of Georgia plume using leaf tissue as the explant source (Woo and Wetzstein, 2008). This method has proven suitable for field-grown material collected from mature specimens of different populations. Adventitious structures are induced on leaf explants placed on a medium with $10 \mu \mathrm{M}$ thidiazuron (TDZ) $+5 \mu \mathrm{M}$ indole-3-acetic acid (IAA), and shoot expansion proceeds upon subculture to a secondary elongation medium supplemented with (2-isopentenyl) adenine. Shoots readily root ex vitro with high survival rates. Outplanting studies of in vitro-generated plants are underway in native sites. Thus, tissue culture appears to be a promising approach for the propagation and conservation of this rare and threatened plant.

During culture initiation, a variety of proliferating structures are induced that include bud-like clusters, elongated embryo-like protrusions, and shoot-like structures. A number of reports indicate that embryogenic and organogenic regeneration pathways can be induced under identical culture conditions in some species (Castillo et al., 2000; Fiore et al., 1997; Pasternak et al., 1999). TDZ, which is used for culture induction with this regeneration system, is a substituted phenylurea that has potent cytokinin activity in woody plant tissue culture (Huetteman and Preece, 1993). TDZ can promote cell division and differentiation, and can induce somatic embryo and adventitious shoot development. For example, regeneration via shoot organogenesis and somatic embryogenesis was obtained in African violet (Saintpaulia ionantha Wendl.) leaf and petiole explants (Mithila et al., 2003) and leaf tissues of Rosa L. hybrid cultivars (Li et al., 2002) treated with TDZ.

Understanding morphological responses during in vitro culture is critical for understanding regeneration pathways. 

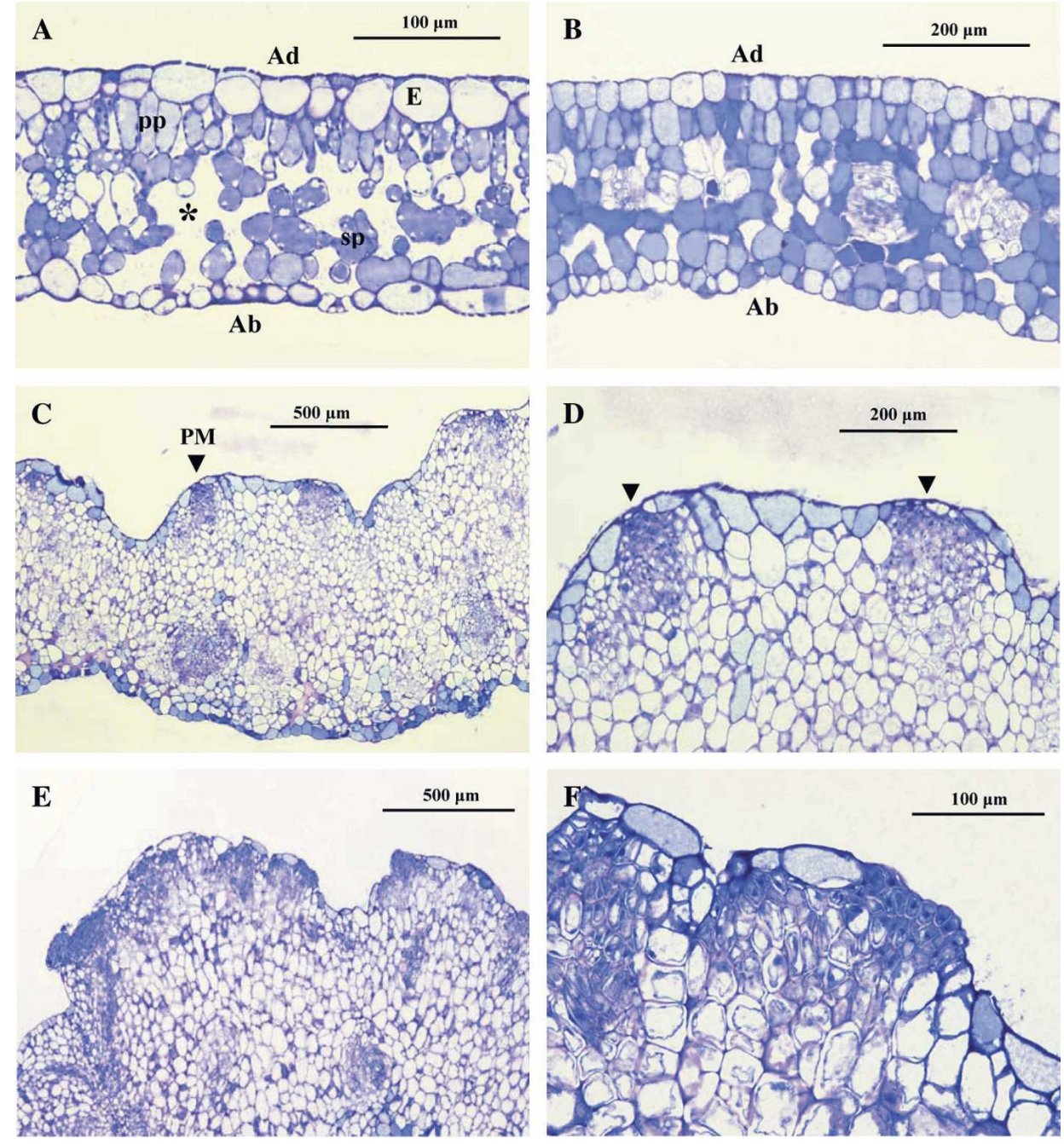

Fig. 1. Light micrographs showing the early stages of induction and morphogenesis of Elliottia racemosa leaf explants cultured on media supplemented with $10 \mu \mathrm{M}$ TDZ and $5 \mu \mathrm{M}$ IAA. (A) Control leaf section showing a uniseriate epidermis (E) with differentiated palisade parenchyma (pp) and spongy parenchyma (sp) cells with prominent intercellular spaces (asterisk). $\mathrm{Ab}=$ abaxial surface, $\mathrm{Ad}=$ adaxial surface. (B) Leaf explant after a 1-week culture on induction medium. Mesophyll cells have divided and enlarged, forming a compact cell organization and a thicker leaf explant. (C) Leaf explant at 2 weeks on induction medium showing massive cell proliferation and formation of meristematic centers. $\mathrm{PM}=$ promeristem. (D) An enlarged view of promeristem regions (point) at 2 weeks on induction medium. (E) Explant after 4 weeks on induction medium. Meristematic activity is most prevalent in subepidermal areas. (F) Cell proliferation causes displacement of epidermal cells after 4 weeks on induction medium.

Recent reports illustrate the importance of histological evaluations of in vitro culture protocols (Bassuner et al., 2007; Haensch, 2004; Madden et al., 2005; Salaj et al., 2005), in that determining the regeneration pathway in a culture system is not always clear. Thus, the objective of this study was to evaluate the induction and development of structures induced on leaf explants of Georgia plume when placed on an induction medium containing TDZ + IAA. Histological evaluations were made using light microscopy (LM) of sectioned material and scanning electron micrography (SEM).

\section{Materials and Methods}

Plant material. Axenically grown shoot cultures of E. racemosa were the source of leaf tissues for culture induc- tion studies. Proliferating cultures were previously established as described by Woo and Wetzstein (2008). Leaves were collected from shoot elongation cultures and were placed on induction medium for developmental and histological studies. Briefly, young, expanding leaf tissue was cut into $\approx 5 \times 5$-mm pieces and then placed abaxial side down onto $\mathrm{GB}_{5}$ medium (Gamborg et al., 1968) supplemented with $10 \mu \mathrm{M}$ TDZ, $5 \mu \mathrm{M}$ IAA, $10 \mathrm{mg} \cdot \mathrm{L}^{-1}$ thiamine $\mathrm{HCL}, 1 \mathrm{mg} \cdot \mathrm{L}^{-1}$ pyridoxine, $1 \mathrm{mg} \cdot \mathrm{L}^{-1}$ nicotinic acid, $40 \mathrm{~g} \mathrm{~L}^{-1}$ maltose, and $4 \mathrm{~g} \mathrm{~L}^{-1}$ Gel-Gro (ICN Biomedicals, Aurora, OH). The $\mathrm{pH}$ of the medium was adjusted to $\mathrm{pH}$ 6.0 before autoclaving at $121^{\circ} \mathrm{C}$ for $20 \mathrm{~min}$. The medium was then dispensed into 90-mm-diameter petri dishes with $30 \mathrm{~mL}$ per plate. Explants were cultured under a $16-\mathrm{h}$ photoperiod in a growth room using white fluorescent lights (70 $\mu \mathrm{mol} \cdot \mathrm{m}^{-2} \cdot \mathrm{s}^{-1}$ ) at $25{ }^{\circ} \mathrm{C}$. Cultures were collected at various times from induction and were prepared for microscopic evaluations.

Histological methods. Leaf explants were collected at $0,1,2$, 3 , and 4 weeks from initiation and were prepared for SEM and LM. For SEM, leaf tissues $1 \mathrm{~cm}^{2}$ or smaller were fixed in $2 \%$ glutaraldehyde in $0.1 \mathrm{M}$ cacodylate buffer for $4 \mathrm{~h}$, washed in the same buffer, and dehydrated in an ethanol series $(25 \%$, $35 \%, 50 \%, 65 \%, 75 \%, 85 \%, 95 \%$, and $100 \%)$. Samples were critical point dried with carbon dioxide using a Samdri-780 critical point drier (Tousimis Research Corp., Rockville, MD), mounted on aluminum stubs using carbon conductive tabs, and then sputter-coated with 60-nm gold using a SPI-Module (SPI Supplies Division, Structure Probe, West Chester, PA). Samples were observed with a 5200 scanning electron micrograph (JEOL, Tokyo) at $15 \mathrm{kV}$. Images were captured digitally. For LM, explants at different stages were fixed in Histochoice tissue fixative (Amresco, Solon, $\mathrm{OH}$ ) and dehydrated through a graded ethanol series from $25 \%$ to $95 \%$. Tissues were then infiltrated and embedded into glycol methacrylate (JB-4 Embedding Kit; Polysciences, Warrington, PA). Infiltration was with daily changes in an EtOH:infiltration medium series [75:25, 50:50, 25:75, 5:95, and 0:100 (by volume) three times]. Tissues were finally embedded into JB-4 medium. Serial sections, $5 \mu \mathrm{m}$ thick, were cut using a rotary microtome (Microm, Heidelberg, Germany), mounted on slides, and stained by immersion in $0.1 \%$ toluidine blue. Sections were observed and photographed with a BX51 Research Microscope (Olympus America, Center 
Valley, PA). For cell size and leaf thickness measurements, 10 leaf cross-sectional areas per treatment were measured.

\section{Results}

At the time of explanting (day 0 ), Georgia plume leaves exhibited the typical cellular organization found in leaf tissue (Fig. 1A). Leaves of Georgia plume had a uniseriate epidermis with differentiated palisade and spongy mesophyll layers. Leaves in cross-section were composed of seven to nine cell layers, and prominent intercellular air spaces were observed in the spongy layer. Stomata were confined to the abaxial epidermis surface. Leaf surfaces had generally flat contours with epidermal cells and raised minor vein areas evident in SEM observations (Fig. 2A). Trichomes were occasionally seen on adaxial and abaxial surfaces.

Incubation of leaf explants on induction medium caused a dramatic enlargement and swelling of tissues. After culture for 1 week, overall leaf thickness increased 2.6fold (from 185 to $478 \mu \mathrm{m}$ on average; Fig. 1B and Table 1). This increase was caused by cell division and cell enlargement. The number of cell layers increased by 1.5 times. Hypertrophy of cells was evident, with mesophyll height and spongy cell diameter increasing by 1.5 - and 1.8-fold, respectively. This led to a more compact mesophyll cell organization in which tissues were composed of more numerous and larger cells with fewer intercellular spaces.

Massive cell proliferation and growth were observed in explants at 2 weeks on induction medium (Fig. 1C). Cell division occurred throughout internal cell layers, resulting in an undifferentiated mesophyll region. Mean leaf thickness increased another 1.8-fold in the additional week on induction medium, which represented a 4.6-fold increase compared with leaves at time zero (Table 1). The number of cell layers increased to 18 to 22 cells thick, and mesophyll and spongy cells increased to twice their original lengths. In addition to the more global cell proliferation found in mesophyll areas, localized regions of intense mitotic activity were observed close to the explant surface, forming promeristem structures (Fig. 1C and D). These divisions were generally confined to the outer several mesophyll cell layers; mitotic activity of adjacent epidermal cells was limited so that mitotic centers on the leaf surface appeared to be bounded by enlarged epidermal cells. These meristematic centers were composed of small, densely staining cells with high cytoplasmic content, and they formed mounded protuberances on the explant surface (Fig. 2B).

At 3 to 4 weeks of culture, more extensive cell proliferation was observed. Numerous densely staining meristematic regions formed in proximity to explant surfaces (Fig. 1E). In some areas, these mitotic areas coalesced, forming sectors of actively dividing cells at the surface. As cell proliferation progressed, displacement or discontinuities in epidermal cells were observed so that meristematic cells were on the explant surface, with actively dividing areas organizing into layers suggestive of early apical meristem formation (Fig. 1F).

Further enlargement of cell clusters formed domed apical meristems, with some meristems exhibiting early meristem and leaf buttress formation (Fig. 3A). Apical meristems exhibited tunica-corpus organization, and vacuolated parenchymatous cells subtended apical meristem regions (Fig. 3B). Adventitious shoots with leaf primordia were numerous (Fig. 3D and I) and had provascular strands (Fig. 3C and D). Evaluations of serial sections confirmed that vascular cells led to explant tissues with no organized root meristem observed. Adventitious shoot 
Table 1. Characteristics of E. racemosa leaf explants placed on induction media containing $10 \mu \mathrm{M}$ TDZ and $5 \mu \mathrm{M}$ IAA at different times after placement on induction medium.

\begin{tabular}{|c|c|c|c|}
\hline & $0 \mathrm{wk}$ & $1 \mathrm{wk}$ & $2 \mathrm{wk}$ \\
\hline Leaf explant characteristic & ------------------ & $(\text { mean } \pm \mathrm{SD})^{\mathrm{z}}$ & ----------------- \\
\hline Cell layers (no.) & $7.8 \pm 0.79 \mathrm{a}^{\mathrm{y}}$ & $12.2 \pm 0.92 \mathrm{~b}$ & $19.9 \pm 1.4 \mathrm{a}$ \\
\hline Mean leaf thickness $(\mu \mathrm{m})$ & $185 \pm 7.1 \mathrm{a}$ & $478 \pm 12.5 b$ & $860 \pm 25.9 \mathrm{a}$ \\
\hline Mean palisade cell ht $(\mu \mathrm{m})$ & $17 \pm 1.6 \mathrm{a}$ & $26 \pm 1.6 \mathrm{~b}$ & $35 \pm 2.0 \mathrm{a}$ \\
\hline Mean spongy cell diam $(\mu \mathrm{m})$ & $21 \pm 1.4 \mathrm{a}$ & $37 \pm 1.9 \mathrm{~b}$ & $45 \pm 2.3 \mathrm{a}$ \\
\hline
\end{tabular}

${ }^{\mathrm{z}}$ Values are means of 10 leaf cross-sectional measurements per collection period.

'Mean separation within rows by Tukey's Studentized range test at $P \leq 0.05$.
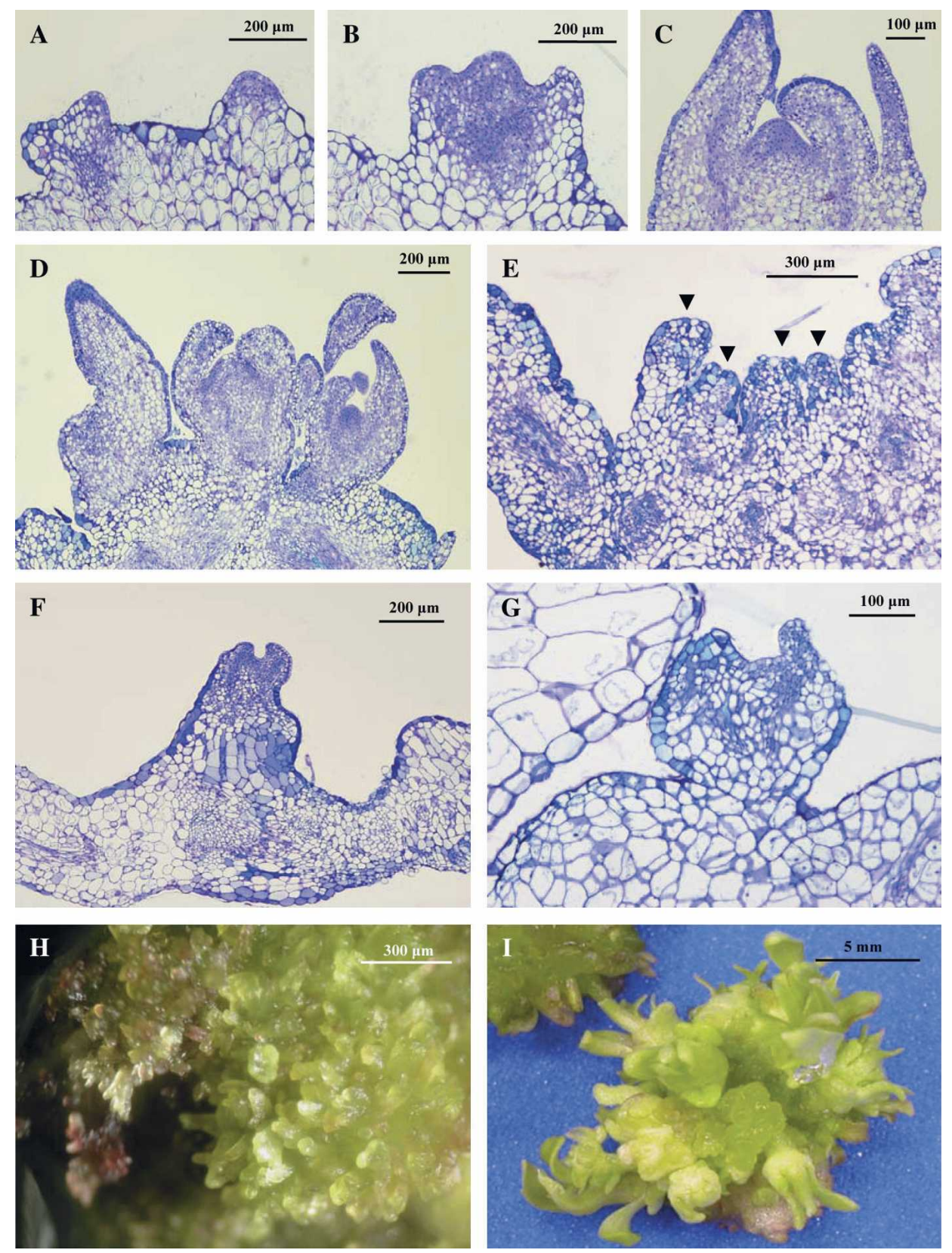

Fig. 3. Light micrographs showing the sequence of development of adventitious shoot buds on Elliottia racemosa leaf explants cultured on media supplemented with $10 \mu \mathrm{M} \mathrm{TDZ}$ and $5 \mu \mathrm{M}$ IAA. (A) Meristematic structures have differentiated at the explant surface. (B) Shoot apex with tunica-corpus organization. (C) Shoot apex with leaf primordia and development of vascular tissue. (D) At 4 weeks on induction medium, numerous shoot primordia have formed along the explant surface. (E) Multiple elongated structures lacking defined meristems (points). (F) Elongated structure with a defined apical meristem, but lacking a root apex and bipolarity. (G) Heart-shaped embryo-like structure, but lacking a root pole. (H) Elongated protrusions. (I) Numerous buds and shoots. formation was not synchronized. Primordia at stages ranging from early protuberances to organized shoots with numerous leaf primordia were observed on the same explant (Figs. 2C and D, and 3I).

Regenerated structures were quite variable. In addition to the shoot-like structures described above, elongated, tubular structures reminiscent of somatic embryos were observed (Fig. 3H). As evidenced with SEM, some of these structures were club-like or fanshaped at apical areas, whereas others had organized apical regions (Fig. 2E-G). LM determined that elongated structures were composed primarily of files of vacuolated cells that were organized as multiple structures with varying degrees of fusion (Fig. 3E) or as single structures (Fig. 3F). Shoot meristem development likewise varied. Evaluations of serial sections showed that no organized root meristems were observed and that structures had a broad base of attachment to parent tissues (Fig. $3 \mathrm{~F}$ and $\mathrm{G}$ ), indicating that somatic embryogenesis did not occur.

\section{Discussion}

Our results indicate that plant regeneration of Georgia plume occurs though a shoot organogenic pathway in leaf explants induced on a medium with TDZ + IAA. Patterns of shoot organogenesis involve the formation of actively dividing meristematic regions originating in subepidermal cell layers. Similar structures have been referred to by a number of terms, including meristemoids, promeristems, and meristemoidlike precursors (Hicks, 1994). We have adopted the terminology of Colby et al. (1991), who define a promeristem as a 
meristematic center, arising de novo and consisting of a small number of densely staining, thin-walled cells, each containing a large, prominent nucleus. Promeristems in the current study continued proliferation and displaced epidermal cells so that the de novo shoot meristems were positioned on the explant surface.

A number of different types of structures were regenerated in this study, which used TDZ + IAA for induction. Our histological evaluations show that numerous well-formed shoot apical meristems were produced. However, fused shoot-like structures, tubular/elongated structures, and undifferentiated protuberances were observed as well. Some lacked an apical meristem. In histological studies by Krug et al. (2005), adventitious structures and protuberances that failed to develop into buds were observed in addition to shoot meristems. Some of these structures were thought to be isolated leaf primordia that are incapable of regenerating new plants. Stipp et al. (2001) similarly verified that nonregenerative protuberances are more frequently formed than complete bud shoots in Cucumis melo L. cultures, resulting in a low frequency of plant recovery.

Organogenic and embryogenic morphogenic pathways have been reported to occur simultaneously in the same culture conditions. Detailed histological analyses in Arabidopsis thaliana (L.) Heynh. indicate that three classes of regenerative structures were produced on the same 2,4-D-amended medium: adventitious shoots, fused shoots, and somatic embryos (Bassuner et al., 2007). Plantlets were regenerated in barley (Hordeum vulgare L.) through various pathways that included somatic embryos from soft and compact calli and multiple shoots from green spots on compact callus (Pasternak et al., 1999). In our tissue culture studies with E. racemosa (Woo and Wetzstein, 2008), plant regeneration was obtained when shoots were excised and rooted. Germination and conversion of embryo-like structures were not obtained.

Histological evaluations of Georgia plume cultures failed to identify true somatic embryo development. Although some globular- and heart-shaped structures were observed that were suggestive of proembryo development, no bipolar structures with defined root meristems were detected as would be anticipated in later embryogenic stages of development. Elongated, embryo-like structures identified from external observations lacked a defined root apex, and were composed at basal portions of parenchymatous files of cells with a broad point of attachment to the parent tissue. Various degrees of shoot apex development were found in elongated structures, ranging from meristems exhibiting histological zonations to those lacking meristem development. Anthony et al. (2004) reported obtaining somatic embryogenic cultures in Leucopogon verticillatus R. Br. using a medium with plant growth regulators similar to the current study, i.e., $10 \mu \mathrm{M}$ TDZ $+5 \mu \mathrm{M}$ IAA. Somatic embryos were not germinated directly; instead, somatic embryos were transferred from parent tissue to one-half-strength basal medium for elongation and then subsequently rooted on indole3-butyric acid (IBA)-containing medium. Structures shown resembled some of the elongated structures obtained in Georgia plume cultures. Histological evidence was not provided to verify if regenerated structures were true somatic embryos (with root apices), partial somatic embryos, or shoots.

As suggested by Bassuner et al. (2007), many published reports dealing with somatic embryogenesis should be reevaluated critically. In a number of cases, histological reevaluations of in vitro cultures show no recognizable root apex.
Such was the case in Pelargonium L'Her. ex Ait (Haensch 2004; Madden et al., 2005) and flax (Linum usitatissimum L.; Salaj et al., 2005). Madden et al. (2005) proposed that "embryo-like" or "partial somatic embryogenesis" be used to describe structures in which all of the criteria for somatic embryogenesis are met except formation of a root pole.

TDZ can induce embryogenesis and organogenesis, with the concentration of TDZ determining the regeneration pathway. In African violet, low concentrations of TDZ $(<2.5 \mu \mathrm{M})$ induced shoot organogenesis, whereas high concentrations of TDZ $(5-10 \mu \mathrm{M})$ induced somatic embryos (Mithila et al., 2003). Similarly, pigeonpea (Cajanus cajan L. Millsp) seedlings cultured on low $(0.05-1.0 \mu \mathrm{M})$, intermediate $(5 \mu \mathrm{M})$, or high $(10-20 \mu \mathrm{M})$ concentrations of TDZ induced multiple shoots, clusters of leafy structures, or somatic embryos, respectively (Singh et al., 2003). In Pelargonium, embryo-like structures and shoot organogenesis formation were observed on the same individual explant ( $\mathrm{Li}$ et al., 2002; Madden et al., 2005). The use of the appropriate concentration and type of plant growth regulators can separate somatic embryogenesis and organogenesis pathways of development (Gaj, 2004). Histological evaluations conducted in conjunction with media manipulation studies are a means to improve culture efficiency, and can provide information to allow the application of the most appropriate strategies for plant regeneration.

\section{Literature Cited}

Anthony, J.M., T. Senaratna, K.W. Dixon, and K. Sivasithamparam. 2004. Somatic embryogenesis for mass propagation of Ericaceae: A case study with Leucopogon verticillatus. Plant Cell Tissue Organ Cult. 76:137-146.

Bassuner, B.M., R. Lam, W. Lukowitz, and E.C. Yeung. 2007. Auxin and root initiation in somatic embryos of Arabidopsis. Plant Cell Rpt. 26:1-11.

Bozeman, J.R. and G.A. Roger. 1983. Final status report in Elliottia racemosa Muhl. Ex Ell., the Georgia plume. U.S. Dept. Interior, Fish and Wildlife Serv., Region IV.

Castillo, P., J. Marquez, A. Rubluo, G. Hernandez, and M. Lara. 2000. Plant regeneration from callus and suspension cultures of Valeriana edulis ssp. procera via simultaneous organogenesis and somatic embryogenesis. Plant Sci. 151:115-119.

Colby, S.M., A.M. Juncosa, J.A. Stamp, and C.P. Meredith. 1991. Developmental anatomy of direct shoot organogenesis from leaf petioles of Vitis vinifera (Vitaceae). Amer. J. Bot. 78:260-269.

Ewan, J. 1968. William Bartram: Botanical and zoological drawings. Memories Amer. Phil. Soc. 74:1-180.

Fay, M.F. 1992. Conservation of rare and endangered plants using in vitro methods. In Vitro Cell. Dev. Biol. Plant 28:1-4.

Fiore, M.C., T. Trabace, and F. Sunseri. 1997. High frequency of plant regeneration in sunflower from cotyledons via somatic embryogenesis. Plant Cell Rpt. 16:295-298.

Gaj, M.D. 2004. Factors influencing somatic embryogenesis induction and plant regeneration with particular reference to Arabidopsis thaliana (L.). Heynh. Plant Growth Regulat. 43:27-47.

Gamborg, O.L., R.A. Miller, and K. Ojima. 1968. Nutrient requirements of suspension cultures of soybean root cells. Exp. Cell Res. 50:151-158.

Godt, M.J.W. and J.L. Hamrick. 1999. Population genetic analysis of Elliottia racemosa (Ericaceae), a rare Georgia shrub. Mol. Ecol. 8:75-82.

Haensch, K.T. 2004. Morpho-histological study of somatic embryolike structures in hypocotyls cultures of Pelargonium $\times$ hortorum Bailey. Plant Cell Rpt. 22:376-381.

Hicks, G.S. 1994. Shoot induction and organogenesis in vitro: A developmental perspective. In Vitro Cell. Dev. Biol. Plant 30:10-15. 
Huetteman, C.A. and J.E. Preece. 1993. Thidiazuron: A potent cytokinin for woody plant tissue culture. Plant Cell Tissue Organ Cult. 33:105-119.

Krug, M.G., L.C.L. Stipp, A.P.M. Rodriguez, and B.M.J. Mendes. 2005. In vitro organogenesis in watermelon cotyledons. Pesquisa Agropecuaria Brasileira, Brasilia 40:861-865.

Li, X., S.F. Krasnyanski, and S.S. Korban. 2002. Somatic embryogenesis, secondary somatic embryogenesis, and shoot organogenesis in Rosa. J. Plant Physiol. 159:313-319.

Madden, J.I., C.S. Jones, and C.A. Auer. 2005. Modes of regeneration in Pelargonium $\times$ hortorum (Geraniaceae) and three closely related species. In Vitro Cell. Dev. Biol. Plant 41:37-46.

Mithila, J., J.C. Hall, J.M.R. Victor, and P.K. Saxena. 2003. Thidiazuron induces shoot organogenesis at low concentrations and somatic embryogenesis at high concentrations on leaf and petiole explants of African violet (Saintpaulia ionantha Wendl.). Plant Cell Rpt. 21:408-414.
Pasternak, T.P., V.A. Rudas, H. Lorz, and J. Kumlehn. 1999. Embryogenic callus formation and plant regeneration from leaf base segments of barley (Hordeum vulgare L.). J. Plant Physiol. 155:371-375.

Patrick, T.S., J.R. Allison, and G.A. Krakow. 1995. Protected plants of Georgia. Georgia Department of Natural Resources, Social Circle.

Salaj, J., B. Petrovska, B. Obert, and A. Pret'ova. 2005. Histological study of embryo-like structures initiated from hypocotyls segments of flax (Linum usitatissimum L.). Plant Cell Rpt. 24:590-595.

Singh, N.D., L. Sahoo, N.B. Sarin, and P.K. Jaiwal. 2003. The effect of TDZ on organogenesis and somatic embryogenesis in pigeonpea (Cajanus cajan L. Millsp). Plant Sci. 164:341-347.

Stipp, L.C., B.M.J. Mendes, S.M.D. Piedade, and A.P.M. Rodriguez. 2001. In vitro morphogenesis of Cucumis melo var. inodorus. Plant Cell Tissue Organ Cult. 65:81-89.

Woo, S.M. and H.Y. Wetzstein. 2008. An efficient tissue culture regeneration system for Georgia plume, Elliottia racemosa, a threatened Georgia endemic. HortScience 43:447-453. 